\title{
Role of Teacher and Parents in Solving Students Learning Difficulties
}

\author{
Fauziah Zainuddin \\ Institut Agama Islam Negeri \\ Palopo \\ South Sulawesi, Indonesia \\ fauziahzain73@gmail.com
}

\author{
H. Halim \\ Institut Agama Islam Negeri \\ Palopo \\ South Sulawesi, Indonesia
}

\author{
R. Zainuddin \\ Institut Agama Islam Negeri \\ Palopo \\ South Sulawesi, Indonesia
}

\begin{abstract}
This study aims to reveal the forms of students' learning difficulties, efforts and cooperation of parents and teachers to solve. Based on these objectives, then I set the primary research sites at DDI 2 Palopo. As the data source is the $5^{\text {th }}$ grade students with 31 students as respondent. Data collection technique is questionnaires technique and interviews technique. The data then processed by tabulating frequency and analyzed qualitatively. The results showed; (1) The difficulties faced by students such as the difficulty to concentrate and understanding teacher's explanations, difficulty in answering the teacher's questions, the difficulty to quiet in class, difficulty practicing chant, wudhu' ' and prayer. (2) Efforts of parents and teachers in dealing with learning difficulties students are teachers used variety of teaching methods. Teachers and parents do the individual approach to students, provide training to students and provide learning facilities. Model cooperation of parents and teachers in dealing with students' learning difficulties, among others: make the cooperation program, socialization program individually to students, making focus group discussion, evaluation reports monthly, involving teachers' guidance and counseling, as well as the school more proactive establish communication, coordination with the parents.
\end{abstract}

Keywords-learning difficulties; teacher, parents

\section{INTRODUCTION}

During this time, the teacher accused as the party responsible for the poor quality of education. The accusation could be true because the teacher's role is strategic and directly involved in learning but the teacher is not the only party that determine learning. Learning takes place with both the necessary cooperation between teachers, parents and the community.

In educational and school improvement aspect, the parent's role is a significant factor [1]-[3]. The role of parents in the study include many aspects [4]. The first aspect is pparenting that parents are responsible for implementing education. The second aspect is ccommunicating is active communication between parent and educator / school. The third aspect is vvolunteering i.e. parents contribute time, energy, thoughts, and other resources to support the school program. The fourth is learning at home is to guide students when studying at home. The fifth is ddecision making of actively parents involved in decision-making, activities, and school policies. The last is ccollaborating with the community is a form of parental involvement in the community in order to promote education. Parental participation in learning is not just sending their children to school and pay dues, but more in a sense of responsibility towards educational success.

Teachers can ask the help of parents to help their children complete homework, watching television schedule, and motivate children to learn [5], [6]. Through the improvement of teaching in schools, teachers and parents need a container as a communication vehicle that can bridge the learning needs of learners. Based on this view also there is a breakthrough that leads to a pattern of cooperation between parents and teachers in dealing with learning difficulties students to enhance learning, so that the success achieved is the result of a harmonious blend between parents and teachers.

Based on the description of the above problems, i see the importance of efforts involving the parent role, communities and teachers to the success of children in school either directly or indirectly. In this context of the author intends to reveal the form of students 'learning difficulties as well as revealing the role model of parents, communities and teachers in addressing students' learning difficulties in SD Darudda'wah Wal Irsyad (DDI) 2 at Palopo city.

\section{SOME PERSPECTIVES}

\section{A. Cooperation of parents and teachers}

First,

Family and school cooperation carried out in several activities, among others: (1) Hold a meeting with parents on a new admission. (2) Conducting correspondence between school and family. (3) The report on the study of students to parents. (4) Visit a home schooling parent or parents to visit the school. (5) Hold a celebration, a party school, or exhibition of the work of learners. (6) Establish associations of parents of learners and teachers [7], [8].

The communication patterns of parents and children in family education [9]. He talks about parents, children, and education in the family that includes the family as an institution, family functioning, family and educational values, 
parenting parents in the family, the responsibility of parents in educating children, as well as some mistakes in the family education.

\section{B. The student learning difficulties}

Learning difficulties is a condition in which the students cannot learn naturally, due to the threats, obstacles or impairments of learning [9].

\section{RESEARCH METHOD}

This study is a survey with a quota sample of 31 in the 5 th grade students as respondents from 176 total students. To them I did interview and with questionnaires as data collection techniques. Then the data analyzed and linked up to the conclusion.

\section{RESUlTS AND DiscUSSION}

\section{A. Difficulties of student learning and the factors that influence}

In this study, learning difficulties experienced by students based on observations in the classroom, among others: difficulty concentrating in understanding the material explanation of teachers, difficulty in answering the teacher, the difficulty being quiet in class and tend to cause noise, and difficulty performing practices mengaji, wudu ', and the practice of prayer.

The above conditions can handled temporarily by considering factors that theoretically could affect learning difficulties. These factors are internal factors - mental and students' minds - and external factors involving social environment, family, teachers, and school.

\section{B. Parents efforts to overcome student learning difficulties}

The main step is parents do know the extent of his desire to seek knowledge through a bridge of communication with the child. This done to gauge what will done strategically to the development of children's education.

\section{Teachers efforts to overcome student learning difficulties}

Some of the steps taken by Islamic education teacher and classroom teacher in backing help students overcome learning difficulties, namely; Using various teaching methods, Personal approach to students, and Training.

\section{CONCLUSION}

Based on the above discussion, it deduced as follows: the forms of students' learning difficulties in SD DDI 2 Palopo in the subjects of Islamic Religious Education, among others: the difficulty in understanding the teacher's explanations concentration, difficulty in answering the questions of teachers, difficulties quiet in class, and difficulty performing practices chant, ablution and prayer. The factors that affect these difficulties is family factors, environmental factors, school factors, teacher factors, and factors of learning burnout or mental fatigue.

Enterprises parents in overcoming learning difficulties students are: (1) Providing guidance, (2) The provision of advice, (3) Supervision of learning, (4) Provision of motivation and reward, and (5) Meeting the learning needs;

Enterprises teachers are: (1) Using the variety of teaching methods, (2) an individual approach to students, (3) Provide training to students, and (4) Provide guidance.

Community efforts in this regard is the school committee to collect data on the socioeconomic conditions of families of students who will be used as material analysis in providing treatment in terms of learning difficulties.

The model of cooperation between parents, teachers and the community in addressing students' learning difficulties are: (1) the management model, (2) a model of collaboration, and (3) strengthening models.

\section{REFERENCES}

[1] J. L. Epstein, School, family, and community partnerships: Preparing educators and improving schools. Westview Press, 2010.

[2] P. Epstein, "School family and Community partnerships: Overview and International Perspectives," in Education is Partnership Conference, 1996, pp. 21-24.

[3] D. Safran, The psychology and politics of parent involvement, vol. 8. The Emirates Center for Strategic Studies and Research, 1997.

[4] M. Nelson, "Empowering Parents for Student Success," Empowering parents to improve educational opportunities for their child, 2016. [Online]. Available: https://medium.com/carnegie-corporation-educationprogram/empowering-parents-for-student-successaef0875e3214.

[5] P. D. Eggen and D. P. Kauchak, Educational psychology: Windows on classrooms. Prentice Hall, 2007.

[6] The Parent Institute, "Seven Proven Ways to Motivate Children To Do Better in School."

[7] M. N. Purwanto, "Ilmu Pendidikan Teori dan Praktek," Bandung PT. Remaja Rosdakarya, 2004.

[8] M. Agabrian, "Relationships Between School and Family: the adolescents' perspective," in Forum Qualitative Sozialforschung/Forum: Qualitative Social Research, 2007, vol. 8, no. 1.

[9] S. B. Djamarah, Pola komunikasi orang tua dan anak dalam keluarga (sebuah perspektif pendidikan Islam). Rineka Cipta, 2004. 